\title{
Modification of the passive heamagglutination test for detection of infectious bursal disease virus
}

\author{
Maduike C. O. Ezeibe ${ }^{1 *}$, John O. A. Okoye ${ }^{2}$, Temitope M. Ogunniran ${ }^{1}$, Obianuju N. Okoroafor $^{1}$ \\ Ihuoma E. Ezeala ${ }^{1}$, Augustine A. Ngene ${ }^{1}$ \\ ${ }^{1}$ Department of Veterinary Medicine, University of Nigeria, Nsukka, Nigeria; ${ }^{*}$ Corresponding Author: maduikeezeibe@yahoo.com \\ ${ }^{2}$ Department of Veterinary Microbiology and Pathology, University of Nigeria, Nsukka, Nigeria
}

Received 16 May 2012; revised 12 June 2012; accepted 22 June 2012

\begin{abstract}
To modify the Passive Haemagglutination (PHA) test, a rapid test, used for qauntitative detection of viral antibodies, so that it can be used for determination of viral titres, dilutions of Infectious Bursal Disease Virus (IBDV) were used to sensitize the Red Blood Cells (RBCs) before reacting them with known IBD serum. Also, to improve sensitivity of the test, different RBC concentrations were used for the test. A standard IBDV gave positive PHA reaction upto its 1:2048 dilution. With different IBDV samples, positive PHA reactions occured upto dilutions, ranging from 1:16 to 1:4096. Different RBC concentrations gave different titres for same IBDV samples. With $0.6 \%$ and $0.2 \%$ RBC concentrations, mean PHA titres of IBDV samples increased from 454. $85 \pm 315.32$ to $2396.57 \pm 489.55(P<$ 0.05 ). It was concluded that PHA can be adopted for evaluation of viral titres. To improve sensitivity of the test, use of $0.2 \% \mathrm{RBC}$ is recommended.
\end{abstract}

Keywords: Passive Haemmaglutination Test; Titre of Viruses

\section{INTRODUCTION}

A major problem of the poultry industry in Nigeria is frequent outbreaks of infectious diseases. Infectious Bursal disease has been reported in many parts of the country [1] and various studies in the country have shown that IBD has acquired an endemic status among the Nigerian poultry population [2]. IBD is caused by a virus of the Birnaviridae family [3]. The disease is also a big challenge in many other countries of the world [4-6].

To control IBD, most farms and countries adopt mass vaccination of poultry [7]. Outcome of IBD vaccination however, varies, depending on quality of the vaccines used, handling of the vaccines, level of maternal anti- bodies in the chicks before vaccination, interval between vaccination and IBDV challenge of the chicks and amount of stress on the chicks at time of vaccination [8]. For this reason and to confirm diagnosis of IBD, many tests for detection of IBD antibodies and for detection and isolation of the virus have been developed.

Tests for detection and quantification of IBD antibodies and of the virus, include Agar Gel Precipitation Test (AGPT), Serum Neutralization test (SNT), Enzyme Linked Immunosorbent Assay (ELISA), Flourescent Antibody Test (FAT) and Virus isolation [9-12].

Another test in use for detection and assessement of IBD antibody titres is the Indirect Haemagglutination or Passive Haemagglutination (PHA) test. So far, PHA is done by sensitizing $1 \%$ concentration of human group "O" RBCs with constant concentration of IBDV antigen, for use on dilutions of suspected IBD sera. So, it is able to assess level of IBD antibodies in the sera [12]. The test is inexpensive, simple to perform and rapid. So, there is need to modify it such that it can also be used to measure IBD virus titres.

\section{MATERIALS AND METHODS}

Two-fold serial dilutions of a confirmed IBD virus (National Veterinary Research Institute, Vom, Nigeria) were used to sensitize human group "0" RBCs. RBC concentrations were prepared by the method described by Wosu [13]. Then $0.02 \mathrm{ml}$ of Phosphate Buffered Saline (PBS) was deposited in each well in a row of a microtitre plate. Equal volume $(0.02 \mathrm{ml})$ of the IBD virus was added to the first well in the row and double diluted to get: 1:2, 1:4:1:8, 1:16, 1:32, 1:64; 1:128, 1:256, 1:512, 1:1024, 1:2048, 1:4096 dilutions of the virus. Thereafter, $0.02 \mathrm{ml}$ of the RBC was added to each virus dilution. The IBDV-RBC were mixed well and incubated at $37^{\circ} \mathrm{C}$ for 15 minutes. In a second microtitre plate, $0.02 \mathrm{ml}$ of a confirmed IBD serum (National Veterinary Research Institute , Vom, Nigeria) was deposited in each well in a row. Equal volumes $(0.02 \mathrm{ml})$ of the sensitized RBCs 
from the first microtitre plate, were deposited into wells of the second microtitre plate, corresponding to dilutions of the IBDV used to sensitize them. RBC control wells, containing only PBS and RBCs were included in the protocol.The setup was incubated at $37^{\circ} \mathrm{C}$ till RBCs in the control wells settled.Reciprocal of highest dilution of the IBD virus used to sensitize RBCs that gave passive agglutination was read as PHA titre of the IBDV.

To test effect of RBC concentrations on sensitivity of PHA test for Virus titres, RBC concentrations of $0.6 \%$, $0.2 \%$ and $0.1 \%$ were sensitized with serial dilutions of 14 different IBD virus samples (Vaccines) as already described. The sensitized RBC concentrations were used for PHA test with known IBD positive serum as described earlier.

\section{RESULTS}

The known IBDV sample produced positive PHA reaction with a titre of 2048 . With $0.6 \%$ RBC and $0.2 \%$ RBC concentrations, mean (PHA) IBD virus titres varied from $454.85 \pm 315.32$ to $2396.57 \pm 489.55(\mathrm{P}<0.05)$. RBC control wells of the $0.1 \%$ RBC concentration could not produce distinctive colour change and so titres at that concentration were not read. The IBDV titres (PHA) with $0.6 \%$ and $0.2 \%$ RBC concentrations are as on Table 1.

Table 1. PHA titre of IBD vaccines with $0.6 \%$ and $0.2 \%$ RBC concentrations.

\begin{tabular}{rcc}
\hline IBD Virus & \multicolumn{2}{c}{ PHA Titres } \\
\hline & $\begin{array}{c}\mathbf{0 . 6 \%} \text { RBC } \\
\text { Concentration }\end{array}$ & $\begin{array}{c}\mathbf{0 . 2} \% \mathbf{R B C} \\
\text { Concentration }\end{array}$ \\
1 & Zero & 4096 \\
2 & Zero & 128 \\
3. & 128 & 1024 \\
4. & Zero & 2048 \\
5. & 2048 & 4096 \\
6. & 4096 & 16 \\
7. & Zero & 128 \\
8. & Zero & 1024 \\
9. & Zero & 4096 \\
10. & Zero & 4096 \\
11. & Zero & 4096 \\
12. & Zero & 512 \\
13. & 32 & 4096 \\
14. & 64 & 4096 \\
Mean & $\mathbf{4 5 4 . 8 5} \pm \mathbf{3 1 5 . 3 2}$ & $\mathbf{2 3 9 6 . 5 7 \pm 4 8 9 . 5 5}$ \\
\hline
\end{tabular}

\section{DISCUSSION}

The passive haemagglutination test, modified in this study, for quantitative detection of viral antigens, measures ability of viruses to infect the RBCs. So, it detects presence of only viable viruses. This makes the test specific, as particles of non viable viruses will not be able to infect the RBCs and so, can not be detected. However, its use for detection of viruses can give false negative if the concentration of RBC is more than available viral particles can sensitize (infect).

When PHA is used to assess titres of antibodies, concentration of the known viral antigen is kept constant at a titre high enough to ensure that all the RBCs are infected. So, once the antigen is of high titre, the $1 \%$ RBC concentration currently used for the test [12] will give accurate result.

To use PHA to determine virus titres, demands that only the lowest RBC concentration that gives readable colour change, be used. From results of present study, the best RBC concentration for PHA test for determination of viral titres appears to be $0.2 \%$. With that RBC concentration, PHA test became more sensitive with mean IBD viral titre increasing from $454.85 \pm 315.32$ with $0.6 \% \mathrm{RBC}$ concentration to $2396.57 \pm 489.55(\mathrm{P}<0.05)$. Performing PHA test for viral titres, with this least RBC concentration that gives readable colour change will also make results of the test reproducable between laboratories.

Deng et al. [14] described a Reverse Passive Haemagglutination (RPHA) test for detection of Duck plaque virus, another virus that lacks the haemagglutinin antigen. In RPHA, known specific antibody to the suspected virus is coupled to RBCs which are then added to dilutions of the suspected viral sample. So, the test may give false positive results because, antibodies coupled onto RBCs would adsorb onto both viable viruses and onto dead viruses or onto subunit viruses. On the other hand, with the modified PHA for viral antigens, unviable viruses and subunit viruses will not be able to infect the RBCs. So, PHA for viral antigens may be more specific and yet as sensitive as the Reverse Passive Haemagglutination test.

What is required to modify PHA for evaluation of virus titres is to reverse the procedure for its use in evaluation of antibody titres. The procedure for PHA as serological test, is to keep concentration of the known viral antigen constant while the test sera are serialy diluted. The modification for determination of virus titres, is to maintain constant concentration of a known antiserum of the virus while the viral samples are serialy diluted and used to sensitize the RBCs.

Other diagnostic techniques that measure viability of viruses include, Serum Neutralization Test (SNT) which 
also measures viral infectivity and Enzyme Linked Immunosorbent Assay (ELISA) and Florescent Antibody Technique (FAT) which detect viral nucleoprotein, an antigen essential for viability of viruses. The ELISA and FAT are expensive and require sophisticated laboratory setups while SNT takes a long time before results can be obtained.

PHA is inexpensive, rapid and simple. It can be performed by most laboratory personel even in remote places. Its modification for assessment of titres of viruses including that of the IBDV, will improve viral research, especially in the developing countries, with less sophisticated laboratory setups.

\section{REFERENCES}

[1] Razmyar, J. and Peighanbari, S.M. (2009) Isolation of characterization of a very virulent infectious bursal disease virus from turkey. Acta Virologica, 53, 271-276. doi:10.4149/av_2009_04_271

[2] Nawathe, D.O., Onunkwo, O. and Smith, I. (1978) Serological evidence of infectious bursal disease in wild and domestic birds in Nigeria. Veterinary Record, 102, 444.

[3] Cereno, T.N. (2008) Infectious bursal disease (IBD): Causative agent, diagnosis and prevention. http://www.canadianpoultry.ca/infectious_bursal_disease. $\underline{\mathrm{htm}}$

[4] Siddique, M., Javed, T. and Sabry, M.A. (1987) Incidence and pathology of various poultry diseases prevalent in Faisalabad and surrounding districts. Pakistan Veterinary Journal, 7, 148-154.

[5] Vanderluis, W. (1999) World poultry disease update. World Poultry, 15, 30-33.
[6] Pitcovski, J., Gutter, B., Gallil, I.G., Goldway, M., Perelman, B., Gross, G., Krispel, S., Barbacov, M. and Michael, A. (2003) Development and large scale use of recombinant VP2 vaccine for the prevention of infectious bursal disease of chickens. Vaccine, 21, 4736-4743.

[7] Vieltiz, E. (1993) Aspects of protection against Gumboro virus. Zoo International, 16, 42-49.

[8] Hair-Bejo, M., Ng, M.K. and Ng, H.Y. (2004) Day old vaccination against infectious bursal disease in broiler chickens. Internatial Journal of Poultry Science, 3, 124128. doi:10.3923/ijps.2004.124.128

[9] Ide, P.R. (1995) A comparison of gel diffusion, fluorescent antibody and virus isolation methods in experimental and natural cases of infectious bursal disease. Canadian Journal of Comparative Medicine, 39, 183-190.

[10] Herbert, W.J. (1974). Veterinary immunology. Blackwell Scientific Publishing Ltd., London.

[11] Sah, R.L., Kataria, J.M., Arya, S.C. and Vermak, C. (1988) Clinico-pathological manifestation of infectious bursal disease associated with nephrotic lesion in chicken. Indian Journal of Veterinary Pathology, 12, 42-48.

[12] Amin, S.A., Muhammed, S., Sajjad, U.R. and Muhammed, J.A. (1999) Comparative sensitivity of different tests in the diagnosis of infectious bursal disease in Broilers. International Journal of Agriculture \& Biology, 1, 48-50.

[13] Wosu, L.O. (1984) Standardization of red blood cells for haemagglutination test and removal of natural agglutinins. Nigerian Veterinary Journal, 13, 39-42.

[14] Deng, M.Y., Burgess, E.C. and Yuill, T.M (1984) Detection of Duck Plaque Virus by Reverse Passive Hemagglutination test. Avian Diseases, 28, 616-628. doi:10.2307/1590230 